\title{
The potential impact of measures taken by water authorities on greenhouse gas emissions
}

\author{
Anne Marieke Motelica-Wagenaar ${ }^{1}$, Tim A. H. M. Pelsma ${ }^{1}$, Laura Moria ${ }^{1}$, and Sarian Kosten ${ }^{2}$ \\ ${ }^{1}$ Waternet, P.O. Box 94370, Amsterdam, the Netherlands \\ ${ }^{2}$ Department of Aquatic Ecology and Environmental Biology, Institute for Water and Wetland Research, \\ Radboud University, P.O. Box 9102, 6500 HC Nijmegen, the Netherlands
}

Correspondence: Anne Marieke Motelica-Wagenaar (anne.marieke.motelica@waternet.nl)

Published: 22 April 2020

\begin{abstract}
Water authorities responsible for water quantity and water quality management may strongly influence the magnitude of greenhouse gas emissions from the surface waters and the adjacent peat areas within their territories. Climate smart water management (reducing influx of organic matter and improving water quality) is therefore a potentially strong mitigation tool. We hypothesize that climate smart water management has a stronger mitigation potential than reducing emissions from the operational management of a Water Authority. Based on literature data on greenhouse gas emissions from ditches and agricultural peatlands, we present a case study of a Dutch Water Authority - Amstel, Gooi and Vecht (operated by Waternet). We estimate that greenhouse gas emissions from the $195 \mathrm{~km}^{2}$ large peat area within its territory are $470 \mathrm{kt} \mathrm{CO}_{2}$-eq per year. An additional $231 \mathrm{kt} \mathrm{CO}_{2}$-eq yr${ }^{-1}$ is emitted from the water bodies within the $102 \mathrm{~km}^{2}$ large water area territory. Both emissions are considerably higher than the estimated climate footprint of the operational management of the water board $\left(\sim 62 \mathrm{kt} \mathrm{CO}_{2}\right.$-eq per year in 2017$)$. While Waternet strives to have a net zero emission of greenhouse gases related to its operational management by 2020, we postulate that measures (to be taken before 2030) such as the prevention of organic matter and nutrients entering surface waters, the removal of organic carbon from ditches and higher groundwater levels in agricultural peatlands, may reduce greenhouse gas emissions in ditches and agricultural peat meadows with 26 and $27 \mathrm{kt} \mathrm{CO}_{2}$-eq per year, respectively. Measures that are taken to reduce greenhouse gas emissions in water bodies are expected to have a positive impact on water quality as well.
\end{abstract}

\section{Introduction}

In line with the Paris agreement of 2015, the Dutch government aims to reduce greenhouse gas (GHG) emissions (Government of the Netherlands, 2019). The work of the Dutch water boards, responsible for water quantity and water quality management, influences aquatic and terrestrial GHG emissions. However, the Dutch water boards currently are not responsible for dealing with GHG emissions from the water systems they manage. Nevertheless, the Dutch waterboards support climate-change mitigation. The Dutch waterboards have set ambitious goals for energy efficiency (more than $30 \%$ reduction in energy use in 2020 compared to 2005) and renewable energy production (the goal is to be $40 \%$ self-supporting in 2020) (Goorts and Kolkuis Tanke,
2018). Waternet works for the regional water authority Amstel, Gooi and Vecht (AGV) and for the municipality of Amsterdam for water-tasks. Activities conducted by Waternet in the realm of the water cycle in and around Amsterdam result in GHG emissions. Waternet aims to become a net zero emitter of GHGs in 2020 (van der Hoek, 2012). In 2014 the climate footprint of Waternet was calculated as $50 \mathrm{kt} \mathrm{CO}_{2}-$ eq $\mathrm{yr}^{-1}$. To realize the net zero emission ambition, it was decided that measures are required to lower the emissions or to compensate them.

In the climate footprint of the water boards, the emissions in the environment (water bodies and peatlands) are normally not taken into account. These emissions are potentially high. In 2017, the emissions from the decrease in carbon stored in peat soils and peaty soils in The Netherlands were reported as 
6.4 $\mathrm{MtCO}_{2}$-eq, which represents $3.2 \%$ of the $\mathrm{CO}_{2}$-emission in the Netherlands (RIVM, 2019). The emissions of water bodies have not yet been included in the terrestrial GHG balance, but these are potentially high as well (Bastviken et al., 2011). Currently, the magnitude of the emission from inland water has a high uncertainty. In the Netherlands, the number of measurement locations is limited and the existing data is predominantly from peat areas (Koschorreck et al., 2020; Schrier-Uijl et al., 2011; Vermaat et al., 2011).

We hypothesize that climate smart water management has a stronger mitigation potential than reducing emissions from the operational management of a Water Authority. In this paper, a case study of Waternet's GHG emissions is investigated. Questions that are posed include: what are the present GHG emissions in ditches, shallow waters and peat meadows? What is an achievable possible reduction in GHG emissions by 2030 in the area of Water authority of Amstel, Gooi and Vecht? How do these reductions relate to their own company emissions and other emissions in the water management area?

\section{Material and methods}

\subsection{Estimation of operational management related GHG emissions}

The climate footprint of the business operations of AGV consists of Scope 1, 2 and 3 emissions. These emissions are derived from consumption of natural gas, transport fuels and process-related emissions (Scope 1), consumption of heat and electricity (Scope 2), consumption of chemicals, materials for building, transport of residuals, transport of employees (home-work and business transport by own cars or public transport), travelling by plane and outsourced maintenance of the water system (Scope 3). Methods applied in this paper are largely consistent with the "klimaatmonitor" of the Dutch water authorities (Goorts and Kolkhuis Tanke, 2018) and the calculation method developed for drinking water companies (Snip and Oesterholt, 2019). $\mathrm{N}_{2} \mathrm{O}$ emissions are multiplied by a factor $265\left(\mathrm{~g} \mathrm{~g}^{-1} \mathrm{CO}_{2}\right.$-eq/ $\left.\mathrm{N}_{2} \mathrm{O}\right)$ and $\mathrm{CH}_{4}$ emissions are multiplied by factor $28 \mathrm{CO}_{2}$-eq/ $\mathrm{CH}_{4}\left(\mathrm{~g} \mathrm{~g}^{-1}\right)$ comprise the global warming potential of a 100-year time horizon (IPCC, 2014).

The direct process related emissions at the waste water treatment plant (wwtp) and effluent of $\mathrm{N}_{2} \mathrm{O}$ and $\mathrm{CH}_{4}$ are based on measurements of N-load and Chemical Oxygen Demand (COD) and default emission intensities general numbers (Frijns et al., 2008). Besides, $\mathrm{N}_{2} \mathrm{O}$ emissions are measured at wwtp Amsterdam-West.

\subsection{Estimation of GHG emissions from surface waters}

The total area of the water bodies within the territory of Waternet was derived from the national Dutch database (BGT watervlakken). Water types within the territory area (ditches, lakes, canals and ponds) are distinguished based on morphology, soil type and expert judgement in line with the Water Framework Directive (Elbersen et al., 2003). For these water types GHG emissions are estimated as described below. Methane emissions are estimated for all water types, carbon dioxide emissions are estimated for dirched, lakes and ponds only. No nitrous oxide emissions are estimated, due to a lack of data. For each type of water body, the total area is multiplied by an emission factor.

The emission factors of diffusive GHG emissions in ditches and lakes are determined based on the mean methane and carbon dioxide diffusive flux measurements in West-Netherlands by Schrier-Uijl et al. (2011). The mean day-time summer GHG diffusive emissions in these studies were 25 and $2.8 \mathrm{mg} \mathrm{CH}_{4} \mathrm{~m}^{-2} \mathrm{~h}^{-1}$ and 124 and $53 \mathrm{mg} \mathrm{CO}_{2} \mathrm{~m}^{-2} \mathrm{~h}^{-1}$ for ditches and lakes respectively on peat soils. Notably these emissions had a large standard deviation. These numbers are used for all soil types in our approach, though there may be differences in GHG emissions between soil types. Subsequently, we adjusted these day-time summer emission intensities to account for potential diel and seasonal variation as follows.

Diffusive methane and carbon dioxide emissions - Lower GHG emissions in the night and in the winter are expected due to decreased temperatures (Schrier-Uijl et al., 2011; Vermaat et al., 2011; Van der Nat et al., 1998; Xing et al., 2004). However, diffusive emissions have also been found to increase during the night (Harisson et al., 2005). To obtain a conservative estimate of average diel emissions we multiplied day-time diffusive fluxes with $2 / 3$ (based on SchrierUijl et al., 2008). In addition, we assumed summer emissions to account for $70 \%$ of total year-round $\mathrm{CH}_{4}$ and $\mathrm{CO}_{2}$ emissions in ditches (Schrier-Uijl et al., 2011). For lakes, these GHG emissions corrections are not performed, as the temperature in lakes is more stable than in ditches. Besides, higher $\mathrm{CO}_{2}$ emissions were found in winter than in summer in lakes in Denmark (Trolle et al., 2012).

Ebullitive $\mathrm{CH}_{4}$ emissions - the emission of methane through ebullition is often higher than diffusive emissions (Aben et al., 2017; Davidson et al., 2018; Van Bergen et al., 2019), but reliable data is scarce (Aben et al., 2017). To obtain a conservative estimate we assumed ebullition to account for $50 \%$ of total methane emissions from ditches and lakes (Vermaat et al., 2011; Wu et al., 2019).

Total GHG fluxes from ditches and lakes are assumed to be 33 and $18 \mathrm{tCO}_{2}$-eq ha ${ }^{-1} \mathrm{yr}^{-1}$ respectively. These emission factors compare well with fluxes determined based on measurements in Dutch peatland water bodies of $35 \mathrm{tCO}_{2}-$ eq $\mathrm{ha}^{-1} \mathrm{yr}^{-1}$ (Vermaat et al., 2011).

Methane estimated emissions from canals are based on general numbers of $11.6 \mathrm{tCO}_{2}$-eq $\mathrm{ha}^{-1} \mathrm{yr}^{-1}$ as provided by IPCC (2019).

GHG emissions from ponds were estimated with an emission factor of $34 \mathrm{tCO}_{2}$-eq ha ${ }^{-1} \mathrm{yr}^{-1}$, based on measure- 
ments in a Dutch urban pond in the province of Gelderland (Van Bergen et al., 2019).

\subsection{Estimation of GHG emissions from agricultural peatlands}

The estimated emissions in the agricultural grassland on peat are based on the relation with the average ground water levels and corrected for clay layer (Jurasinski et al., 2016; Troost et al., 2018).

\subsection{Potential effect of water management measures to reduce $\mathrm{GHG}$ emissions}

Mesocosm experiments show a distinct effect from nutrient loading, with a two-fold increase in (diffusive and ebullition) methane emissions from high nutrient lakes compared to low nutrient lakes (Davidson et al., 2018). Therefore, we assume that a reduction in nutrient loading can reduce methane emissions by $50 \%$ in eutrophic water bodies.

We assume that ditch depth is inversely related to methane emission intensity, since the shallowing of ditches is almost always caused by the deposition of organic matter fueling methane production, either by strong run-off from the land and erosion or by a strong primary production or both, combined with a lack of ditch management. In most cases, areas with shallow peat ditches are also richer in phosphorus (Van Rotterdam et al., 2019). We assume that methane emissions in shallow eutrophic peat ditches can be reduced by $50 \%$ by 2030 as a result of dredging and consequent deepening of the ditch. The residual emission of the organic matter/sludge removed from the ditch (and partly probably emitted as $\mathrm{CO}_{2}$ instead of $\mathrm{CH}_{4}$ ), is not taken into account.

The potential GHG emissions reduction by water management measures in other water bodies (lakes, canals and ponds) is not quantified.

The potential of lowering the emissions in agricultural peat meadows by 2030 are determined for four measures: a strong raise of groundwaterlevel up to $10 \mathrm{~cm}$ below surface (paludiculture), $20 \mathrm{~cm}$ higher ground water level from 1 April until 1 October, subsurface irrigation by submerged drains and nature development (for the latter measure, it is assumed that nature is a net-zero greenhouse gas emitter). The possible GHG emission reduction for each measure was derived from the relation of mean ground water level and GHG emission (Jurasinski et al., 2016; Troost et al., 2018). The total area where the measures can be taken are based on expert judgement at Waternet.
Table 1. Estimation of methane emissions in water bodies in the water management area of AGV.

\begin{tabular}{lrrr}
\hline Water body & $\begin{array}{r}\text { Emission } \\
\text { factor } \\
{\left[\mathrm{tCO}_{2} \text {-eq }\right.} \\
\left.\mathrm{ha}^{-1} \mathrm{yr}^{-1}\right]\end{array}$ & $\begin{array}{r}\text { Area } \\
{[\mathrm{ha}]}\end{array}$ & $\begin{array}{r}\text { Total } \\
\text { emission } \\
{\left[\mathrm{kt} \mathrm{CO}_{2-}\right.} \\
\left.\mathrm{eq} \mathrm{yr}^{-1}\right]\end{array}$ \\
\hline Ditches & 33 & 3540 & 118 \\
Lakes & 18 & 4753 & 88 \\
Canals & 11.6 & 1710 & 20 \\
Ponds & 34 & 171 & 6 \\
\hline Total & & 10174 & 231 \\
\hline
\end{tabular}

\section{Results and discussion}

\subsection{Estimation of operational management related GHG emissions}

As previously indicated the 2014 emission of AGV was estimated to be $50 \mathrm{ktCO}_{2}$-eq yr${ }^{-1}$. To become a net-zero emitter by 2020 the implementation of several measures are contemplated. It should be noted, however, that since 2014 it has become apparent that the actual emissions of AGV are higher than previously estimated. In 2017, the climate footprint is about $62 \mathrm{ktCO}_{2}$-eq (see Fig. 1). This is despite various measures like energy consumption reduction and solar energy production.

The overall emissions went up largely because of high $\mathrm{N}_{2} \mathrm{O}$ emissions measured at wwtp Amsterdam-West. These emissions were high due to maintenance in this period (28 $\mathrm{kt} \mathrm{CO}_{2}$-eq). Besides, the analysis of emissions is updated and more complete in 2017 than it was in 2014. For the direct process related emissions, the analysis includes all wwtp's of AGV instead of only wwtp Amsterdam-West. Emission factors were used to estimate emissions from the other wwtp's of Waternet.

\subsection{Estimation of GHG emissions from surface waters}

Total GHG emissions from water bodies in the AGV water management area are estimated to be about $231 \mathrm{ktCO}_{2}$ eq $\mathrm{yr}^{-1}$ (see Table 1). The highest surface area of water bodies are lakes (both shallow and deep), but following our assessment, the majority of the methane emissions take place in ditches (see Table 1).

The water management area of AGV consists of about 35 million $\mathrm{m}^{2}$ ditches (of which 24 million $\mathrm{m}^{2}$ in peat areas and 11 million $\mathrm{m}^{2}$ in sand/clay soil). The median water depth is $33 \mathrm{~cm}$. GHG emissions in these ditches are estimated based on measurements in the West of Netherlands in peat ditches.

The IPCC Refinement of 2019 uses another standard emission factor for methane emissions from ditches (and canals) and ponds of 11.6 and $5.12 \mathrm{tCO}_{2}$-eq ha ${ }^{-1} \mathrm{yr}^{-1}$, respectively (which is 3 and 4 -fold lower than our emission factors, re- 


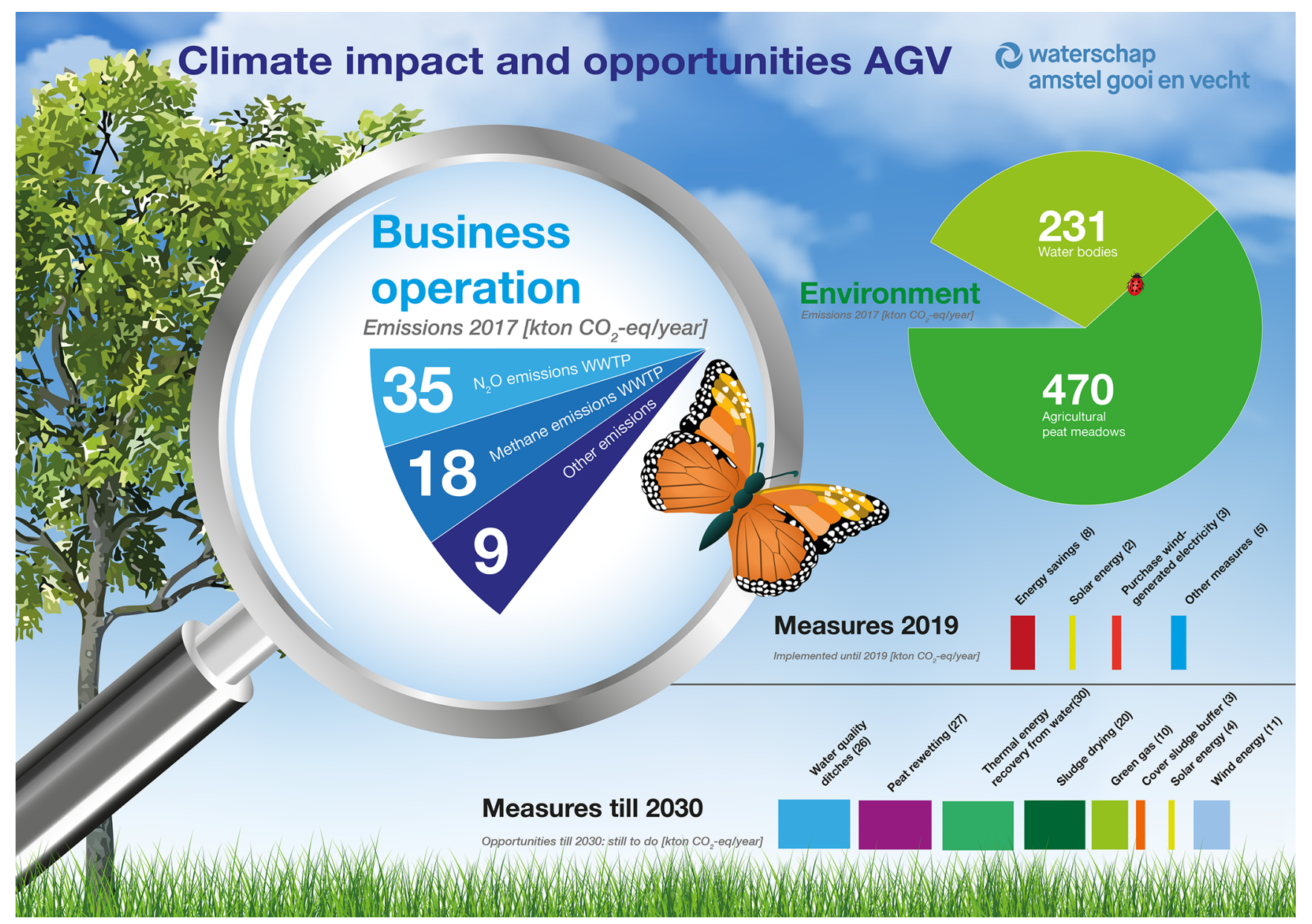

Figure 1. Climate impact and opportunities regional water authority Amstel Gooi and Vecht (AGV). Figure 1 was created by $\odot$ Waternet.

spectively) (IPCC, 2019). These emission factors are used world-wide (IPCC, 2019). If these emission factors are used, the methane emissions of ditches and ponds in the water management area of AGV would be "only" 41 and $1 \mathrm{kt} \mathrm{CO}_{2}$ eq $\mathrm{yr}^{-1}$, respectively. However, in the IPCC Refinement, it is stated that good practice includes the development of country specific emission factors (IPCC, 2019). We argue, that the emission factors in this paper are more representative for the GHG emissions from ditches and ponds in the AGV water management area than the IPCC emission factors. The principle reason is that our emission factors are based on GHG emissions measurements in ditches and lakes in the West of the Netherlands and in a Dutch pond, whereas the IPCC emission factors are based on emissions from ditches and ponds worldwide.

More than half of the ditches in the area of Waternet are shallow eutrophic or hypertrophic. About $20 \%$ of the ditches are hypertrophic (duckweed cover $>10 \%$ ). A $50 \%$ reduction of methane emissions in half of the ditches may imply a reduction of about $26 \mathrm{ktCO}_{2}$-eq $\mathrm{yr}^{-1}$.
Methane emissions can be reduced by removing the sludge, but a more sustainable plan would be preventing organic matter from reaching the ditches. This can be accomplished either by limiting fertilizers (from both sludge and from fields) and inflow of nutrient-rich water and thus limiting the primary production (plant growth, algae) in the ditches. In addition, it is important to slow down or stop the degeneration of nearby (peat) soils, which causes the ditch to fill over time (via run-off) with sludge. Improved submerged vegetation and increased depth will both cause a drop in the temperature of the water and will cause (more) oxygen to reach the sludge via the roots of the plants. All these factors are assumed to reduce the emissions of methane and $\mathrm{CO}_{2}$.

As pointed out earlier, the estimation of methane emissions in ditches is still highly uncertain. To which extent the emissions can be reduced is even more uncertain.

Our assumption that methane emissions will be lowered due to measures targeting a reduction in nutrient loading, for instance, is based on mesocosm experiments (Davidson et al., 2018). In the field, however, so far no consistent differences in methane emissions from eutrophic and mesotrophic 
ditches have been found (Schrier-Uijl et al., 2011). We expect, that this lack of field evidence for the impact of trophic state is likely due to large spatial variations. Although we aimed to be conservative in our estimates, this example highlights that our estimated potential to lower the methane emissions may be overestimated. On the other hand, the temperature induced increase of methane emission will likely strongly increase future methane emissions (Davidson et al., 2018).

Although lakes and canals also fix carbon internally via photosynthesis, lake metabolism is generally a net source of $\mathrm{CO}_{2}$ and $\mathrm{CH}_{4}$ (Sanches et al., 2019; Huttunen et al., 2003). Environmental factors, such as the external organic and nutrient loads, temperature and precipitation act as important driving factors for $\mathrm{CH}_{4}$ emissions. Higher emissions occur where nutrient loading and air temperature and precipitation are high (Sanches et al., 2019; Huttunen et al., 2003). Nutrient loading increases primary production in aquatic systems. Plant biomass decaying under anoxic circumstances in the sediment can increase $\mathrm{CH}_{4}$ release from lakes to the atmosphere. The carbon dioxide fluxes are higher from reservoirs and lakes whose catchment areas are rich in peatlands or managed forests, and from eutrophic lakes in comparison to oligotrophic and mesotrophic sites (Huttunen et al., 2003; Deemer et al., 2016). Within the management area of $\mathrm{AGV}$, numerous measures are implemented to reduce nutrient loading to lakes and canals and to improve their water quality. These measures will also reduce methane emissions from canals and lakes. However, this reduction is not quantified in this study.

Ponds constitute only about $2 \%$ of the total water management area of AGV. However, the GHG emission factor used for this water body is relatively high, compared to lakes (see Table 1).

Urban ponds often receive a lot of organic matter (like drainage ditches) from run-off, street- and roof water, and adjacent water bodies. These ponds are subject to leaves, litter and dog/bird droppings and sometimes even sewage after heavy rainfall. Methane emissions can be reduced by improvement of the roof- and streetwater sewage system (reducing first flush in case of heavy rain).

\subsection{Estimation of GHG emissions from agricultural peatlands}

The water management area of AGV consists of about 19400 ha agricultural peat meadows, which emit about $470 \mathrm{ktCO}_{2}$-eq yr ${ }^{-1}$ (mainly due to oxidation as a consequence of drainage) (Troost et al., 2018; Van den Born et al., 2016). The average emission for drained peat meadows is about $24 \mathrm{tCO}_{2}$-eq ha ${ }^{-1} \mathrm{yr}^{-1}$.

Higher groundwater levels in part of the management area of AGV (rewetting of peatland) may reduce these emissions by about $27 \mathrm{ktCO}_{2}$-eq yr ${ }^{-1}$ by 2030 (see Table 2 ).
Table 2. Calculation of total possible GHG reduction until 2030 for the agricultural peat meadow in the water management area of AGV.

\begin{tabular}{lrrr}
\hline Measure & $\begin{array}{r}\mathrm{GHG} \\
\text { reduction } \\
{\left[\mathrm{tCO}_{2} \text {-eq }\right.} \\
\left.\mathrm{ha}^{-1} \mathrm{yr}^{-1}\right]\end{array}$ & $\begin{array}{r}\text { Area } \\
{[\text { ha }]}\end{array}$ & $\begin{array}{r}\text { Total } \\
\text { GHG } \\
\text { reduction } \\
{\left[\mathrm{ktCO}_{2^{-}}\right.} \\
\left.\mathrm{eq} \mathrm{yr}^{-1}\right]\end{array}$ \\
\hline (1) Paludiculture & 15 & 300 & 4.5 \\
(2) Higher summer groundwater level & 5 & 500 & 2.5 \\
(3) Submerged drains & 0.165 & 1500 & 0.25 \\
(4) Nature & 20 & 1000 & 20 \\
\hline Total & & & 27.25 \\
\hline
\end{tabular}

Transformation from normal agricultural land to paludiculture could be applied at the lowest parts of peat-polders. These lowest parts are in general equipped with extra pumps to keep the meadow dry. It would take little technical effort (mainly switching off the pumps and place some extra weirs) to start paludiculture here. It is estimated that 300 ha could be transformed to paludiculture. These areas have relatively low water levels with high GHG emissions. Therefore, the GHG reduction of $15 \mathrm{tCO}_{2}$-eq ha ${ }^{-1} \mathrm{yr}^{-1}$ is a conservative estimate (Geurts and Fritz, 2018).

It is expected that a $20 \mathrm{~cm}$ higher groundwater level typically measured from 1 April until 1 October will lead to a $10 \mathrm{~cm}$ higher mean annual ground water level, which will lead to an emission reduction of about $5 \mathrm{tCO}_{2}$-eq ha ${ }^{-1} \mathrm{yr}^{-1}$. This could take place at about 500 ha which is a conservative estimate, though it would require changes in the current water management practice. Higher ground water levels are reached by higher water levels in ditches (sometimes water levels will have to be raised more than $20 \mathrm{~cm}$, especially in infiltration areas, alternatively one could dig more irrigation ditches). This could lower the production of the grass and thus have impact on the business of the farmer.

The total potential area for subsurface irrigation by submerged drains has been determined to be about 4500 ha. In this analysis it is assumed that in $1 / 3$ of the potential area these drains can be implemented. The estimation of the GHG reduction is small for this measure, as the potential is based on the difference of the mean annual groundwater level. The subsurface irrigation by submerged drains leads to higher groundwater levels in summer and lower groundwater levels in winter, therefore the mean annual groundwater level is hardly affected. If this irrigation is carried out with active pumping, the emissions of GHG may be reduced by as much as $63 \%$ (Hoving et al., 2018). Subsurface irrigation with pumps has little or slight positive effect on the production on the grassland, but requires an investment of about EUR 2600 per ha (Hoving et al., 2018). Agricultural use remains unchanged.

The transformation of agricultural land to natural habitat is assumed to make the GHG emissions climate neutral. In 
the Dutch climate agreement ("klimaatakkoord 2019") it is stated that 10000 ha agricultural land will be transformed to natural habitat. The water management area of AGV emits about $10 \%$ of the national emission of agricultural peat meadow. Therefore, in this analysis, it is assumed that in the water management area of $\mathrm{AGV}, 1000$ ha is transformed to natural habitat. It is assumed that the wetter peat soils (with lower GHG emissions than average) are first transformed to natural habitat, therefore the estimation of the GHG emission is assumed to be lower than $24 \mathrm{tCO}_{2}$-eq ha ${ }^{-1} \mathrm{yr}^{-1}$ (which is the mean GHG emission of the agricultural peat meadow in the AGV water management area). In Table 2, we present a reduction of $20 \mathrm{tCO}_{2}$-eq ha $\mathrm{hr}^{-1} \mathrm{yr}^{-1}$ in case of transformation to nature, which we derived from both "klimaatakkoord (2019)" and Schrier-Uijl et al. (2014). Schrier-Uijl et al. (2014) measured a reduction of $20.4 \mathrm{tCO}_{2}$-eq ha ${ }^{-1} \mathrm{yr}^{-1}$. They compared rewetted nature (net $\mathrm{CO}_{2}$ sink) with traditional peat meadow (net emission).

For measures 2 and 3 (higher summer ground water level and the subsurface irrigation by submerged drains), the GHG reduction potential is underestimated because the reduction is calculated on the basis of annual ground water levels even though summer water levels are higher. The highest GHG emissions are normally taking place at higher temperatures (Moore and Dalva, 1993).

Measured phosphorous concentrations are higher in shallow ditches with higher groundwater levels in the water management area of AGV (Van Rotterdam et al., 2019). This indicates that rewetting of peat to reduce GHG emissions from the peatland can have side-effects. Wetting of peat, especially when water can run off from the fields or flow out of drainage pipes, could result in an increased phosphorus load tot the ditch. This is because phosphorus in (partly) decomposed peat will become available in anoxic conditions.

\section{Conclusions}

This investigation shows that GHG emissions in the territory of the water board AGV, which are influenced by the water management practices, are much greater than the emissions of the business operations of AGV. Therefore, it may be more effective to implement measures to reduce GHG emissions in the environment than it is to focus only on reduction of the climate footprint of the water company itself. GHG emissions in water bodies (especially ditches and lakes) and agricultural peat meadows are significant.

Water management measures that are aimed at lowering GHG emissions have an impact on water quality. This is especially true for those measures applied to water bodies because a synergy is expected between the lowering GHG emissions and water quality. Since water authorities are experts and have experience in implementing water management measures, water authorities are important stakeholders in lowering the emissions from water bodies and peat- lands. For the implementation of practices aimed at reducing GHG emissions in the environment, cooperation with other stakeholders like farmers is important, since farmers are in most cases owner of the ditches.

Although there are various uncertainties to be addressed, like the origin of the sludge in peatland ditches and the need for more measurements of GHG emissions and the effect of water management measures on these emission, some measures can be taken right way as they are no-regret because besides having a likely positive climate effect they also have other positive effects. These measures on peatland are (in order of decreasing climate effect): improvement of water quality in the ditches, transfer agricultural land to wet nature, summer raise of the ditch levels, paludiculture and pump driven submerged drains.

Data availability. Underlying data is stored in a non-public database of Waternet. Datasets are available by contacting the correspondence author.

Author contributions. AMMW took the lead to write this paper. TAHMP, LM and SK contributed in writing the paper. AMMW is responsible for generating an overview of the climate footprint of Waternet and the measures that will or can be taken by Waternet in general to reduce greenhouse gas emissions. TAHMP made an estimation of the potential to lower the greenhouse gas emissions in peat areas. LM and TAHMP provided measures to reduce methane emissions in ditches. LM provided the specifications of the ditches and lakes of AGV (total surface area, depth, soil type). LM made an estimation of the potential to lower the greenhouse gas emissions in ditches. SK provided background literature to make the estimation of greenhouse gas emissions in surface waters.

Competing interests. The authors declare that they have no conflict of interest.

Special issue statement. This article is part of the special issue "TISOLS: the Tenth International Symposium On Land Subsidence - living with subsidence". It is a result of the Tenth International Symposium on Land Subsidence, Delft, the Netherlands, 17-21 May 2021.

Acknowledgements. The idea of this work was given by André Struker (commissioner). The infographic (Fig. 1) is drawn by Paul van Elk. The data that is provided to calculate the emissions is provided by different workers from Waternet. Hereby some are mentioned though not all: Marcel Zandvoort $\left(\mathrm{N}_{2} \mathrm{O}\right.$ emissions), Jacqueline de Danschutter (measures taken for k2020), Sara Giorgi (thermal energy recovery from water), Bram Konneman (wind energy). Finally the basis for the climate footprint is set by Theo Janse (who is now retired from Waternet). 


\section{References}

Aben, R. C. H., Barros, N., van Donk, E., Frenken, T., Hilt, S., Kazanjian, G., Lamers, L. P. M., Peeters, E. T. H. M., Roelofs, J. G. M., de Senerport Domis, L. N., Stephan, S., Velthuis, M., Van de Waal, D. B., Wik, M., Thomton, B. F., Wilkinson, J., DelSontro, T., and Kosten, S.: Cross continental increase in methane ebullition under climate change, Nat. Commun., 8 , 1682, https://doi.org/10.1038/s41467-017-01535-y, 2017.

Bastviken, D., Tranvik, L. J., Downing, J. A., Crill, P. M., and Enrich-Prast, A.: Freshwater methane emissions offset the continental carbon sink, Science, 331, 50, 2011.

Davidson, T. A., Audes, J., Jeppesen, E., Landkildehus, F., Lauridsen, T. L., Søndegaard, M., and Syväranta, J.: Synergy between nutrients and warming enhances methane ebullition from experimental lakes, Nature Clim. Change, 8, 156-160, 2018.

Deemer B. R., Harrison, J. A., Li, S., Beaulieu, J. J., DelsSontro, T., Barros, N., Bezerra-Neto, J. F., Powers, S. M., Dos Santos, M. A., and Vonk, J. A.: Greenhouse gas emissions from reservoir water surfaces: A new global synthesis, Bioscience, 66, 949-964, https://doi.org/10.1093/biosci/biw117, 2016.

Elbersen, J. W. H., Verdonschot, P. F. M., Roels, B., and Hartholt, J. G.: Definitiestudie Kaderrichtlijn Water (KRW), I. Typologie Nederlandse Oppervlaktewateren, Alterra-rapport 669, available at: https://library.wur.nl/WebQuery/wurpubs/320649 (last access: 24 February 2020), 2003.

Frijns, J., Mulder, M., and Roorda, J.: Op weg naar een klimaatneutrale waterketen, STOWA 2008-17, ISBN 978.90.5773.411.3, available at: https://pdfs.semanticscholar.org/dfde/ 639a3a184fc107ea6c213064bd8a681f0cee.pdf?_ga=2. 70582483.278089143.1582543929-197030730.1582543929 (last access: 24 February 2020), 2008

Geurts, J. and Fritz, C.: Paludiculture pilots and experiments with focus on cattail and reed in the Netherlands. Technical report CINDERELLA project, FACCEJPI ERA-NET Plus on Climate Smart Agriculture, available at: https://www.veenweiden.nl/wp-content/uploads/2018/ 08/Rapportage-Paludicultuur-Radboud-Universiteit.pdf (last access: 24 February 2020), 2018.

Goorts, C. and Kolkhuis Tanke, R.: Klimaatmonitor waterschappen, Verslagjaar 2017, available at: https://www.uvw.nl/wp-content/ uploads/2018/12/Klimaatmonitor-waterschappen-2017.pdf (last access: 24 February 2020), 2018.

Government of the Netherlands: Klimaatakkoord, available at: https://www.klimaatakkoord.nl/documenten/publicaties/2019/ 06/28/klimaatakkoord (last access: 24 February 2020), 2019.

Harrison, J. A., Matson, P. A., and Fendorf, S. E.: Effects of a diel oxygen cycle on nitrogen transformations and greenhouse gas emissions in a eutrophied subtropical stream, Aquat. Sci. 67, 308-315, https://doi.org/10.1007/s00027-005-0776-3, 2005.

Hoving, I. E., van den Akker, J. J. H., Massop, H. T. L., Holshof, G. J., and van Houwelingen, K.: Precisiewatermanagement op veenweidegrond met pompgestuurde onderwaterdrains, Wageningen Livestock Research report No. 1123, Wageningen Livestock Research, Wageningen, https://doi.org/10.18174/461252, 2018.

Huttunen, J. T., Alkm, J., Liikanen, A., Juutinen, S., Larmola, T., Hammar, T., Silvoa, J., and Martikainen, P. J.: Fluxes of methane, carbon dioxide and nitrous oxide in boreal lakes and potential anthropogenic effects on the aquatic greenhouse gas emissions, Chemosphere, 52, 609-621, https://doi.org/10.1016/S0045-6535(03)00243-1, 2003.

IPCC: Fifth assessment report, available at: https://archive.ipcc.ch/ pdf/assessment-report/ar5/syr/SYR_AR5_FINAL_full_wcover. pdf (last access: 24 February 2020), 2014.

IPCC: Refinement to the 2006 IPCC Guidelines for National Greenhouse Gas Inventories, in: chap. 7: Wetlands, available at: https://www.ipcc-nggip.iges.or.jp/public/2019rf/index.html (last access: 24 February 2020), 2019.

Jurasinski, G., Günther, A., Huth, V., Couwenberg, J., and Glatzel, S.: 5.1 Greenhouse gas emissions, in: chap. 5 Ecosystem services provided by paludiculture, Paludiculture - productive use of wet peatlands, Climate protection - biodiversity - regional economic benefits, edited by: Wichtmann, E., Schröder, and Joosten, H., Schweizerbart Science Publishers, Stuttgart, 79-93, 2016.

Koschorreck, M., Downing, A. S., Hejzlar, J., Marcé, R., Laas, A., Arndt, W. G., Keller, P. S., Smolders, A. J. P., van Dijk, G., and Kosten, S.: Hidden treasures: Human-made aquatic ecosystems harbour unexplored opportunities, Ambio, 49, 531-540, https://doi.org/10.1007/s13280-019-01199-6, 2020.

Moore, T. R. and Dalva, M.: The influence of temperature and water table position on carbon dioxide and methane emissions from laboratory columns of peatland soils, J. Soil Sci., 44, 651-664, https://doi.org/10.1111/j.1365-2389.1993.tb02330.x, 1993.

RIVM: Greenhouse gas emissions in the Netherlands 1990-2017, National Inventory Report 2019, available at: https://www.rivm. nl/bibliotheek/rapporten/2019-0020.pdf (last access: 24 February 2020), 2019.

Sanches L. F., Guenet, B., Marinho, C. C., Barros, N., and de Assis Esteves, F.: Global regulation of methane emission from natural lakes, Sci, Rep., 9, 255, https://doi.org/10.1038/s41598-01836519-5, 2019.

Schrier-Uijl, A. P., Veenendaal, E. M., Leffelaar, P. A., van Huissteden, J. C., and Berendse, F.: Spatial and temporal variation of methane emissions in drained eutrophic peat agro-ecosystems: drainage ditches as emission hotspots, Biogeosciences Discuss., 11, 1237-1261, https://doi.org/10.5194/bgd-5-1237-2008, 2008.

Schrier-Uijl, A. P., Veraart, A. J., Leffelaar, P. A., Berendse, F., and Veenendaal, E. M.: Release of $\mathrm{CO}_{2}$ and $\mathrm{CH}_{4}$ from lakes and drainage ditches in temperate wetlands, Biogeochemistry, 102, 265-279, 2011.

Schrier-Uijl, A. P., Kroon, P. S., Hendriks, D. M. D., Hensen, A., Van Huissteden, J., Berendse, F., and Veenendaal, E. M.: Agricultural peatlands: towards a greenhouse gas sink - a synthesis of a Dutch landscape study, Biogeosciences, 11, 4559-4576, https://doi.org/10.5194/bg-11-4559-2014, 2014.

Snip L., and F. Oesterholt: Berekening $\mathrm{CO}_{2}$-voetafdruk van drinkwaterbedrijven, KWR PCD 11:2018, Januari 2019, available at: http://library.wur.nl/WebQuery/hydrotheek/2250061 (last access: 24 February 2020), 2019.

Trolle, D., Staehr, P. A., Davidson, T. A., Bjerring, R., Lauridsen, T. L., Søndergaard, M., and Jeppesen, E.: Seasonal dynamics of $\mathrm{CO}_{2}$ flus across the surface of shallow temperate lakes, Ecosystems, 15, 336-347, 2012.

Troost, S., Kuipers, H., and Hoefsloot, N.: Toekomstverkenning bodemdaling AGV, Report HJGK/001/162262, Aveco de Bondt, Amersfoort, 2018.

Van Bergen, T. J. H. M., Barros, N., Mendonca, R., Aben, R. C. H., Althuizen, I. H. J.,Huszar, V., Lamers, L. P. M., 
Lürling, M., Roland, F., and Kosten, S.: Seasonal and diel variation in greenhouse gas emissions from an urban pond and its major drivers, Limnol. Oceanogr., 64, 2129-2139, https://doi.org/10.1002/lno.11173, 2019.

Van den Born, G. J., Kragt, F., Henkens, D., Rijken, B., van Bemmel, B., and van der Sluis, S.: Dalende bodems, stijgende kosten, Mogelijke maatregelen tegen veenbodemdaling in het landelijk en stedelijk gebied, PBL 1064, available at: https://www.pbl.nl/sites/default/files/cms/publicaties/ pbl-2016-dalende-bodems-stijgende-kosten-1064.pdf (last access: 25 February 2020), 2016.

Van der Hoek, J. P.: Towards a climate neutral water cycle, J. Water Clim., 3, 163-170, https://doi.org/10.2166/wcc.2012.015, 2012.

Van der Nat, F.-J. W. A., Middelburg, J. J., van Meteren, D., and Wielemakers, A.:. Diel methane emission patterns from Scirpus lacustris and Phragmites australis, Biogeochemistry, 41, 1-22, https://doi.org/10.1023/A:1005933100905, 1998.
Van Rotterdam, D., Kros, J., de Pater, J., Vogel, J., and Ros, G. H.: Agrarische fosforbelasting van het oppervlaktewater en het handelingsperspectief binnen het beheergebied van waterschap Amstel, Gooi en Vecht, Rapport 1685.N.16, Nutriënten Management Instituut BV, Wageningen, 2019.

Vermaat, J. E., Hellmann, F., Dias, A. T. C., Hoorens, B., van Logtestijn, R. S. P., and Aerts, R.: Greenhouse gas fluxes from Dutch peatland water bodies: Importance of the surrounding landscape, Wetlands, 31, 493-498, https://doi.org/10.1007/s13157-011-0170-y, 2011.

Wu, S., Li, S., Zou, Z., Hu, T., Hu, Z., Liu, S., and Zou, J.: High methane emissions largely attributed to ebullitive fluxes from a subtropical river draining a rice paddy watershed in China, Environ. Sci. Technol., 53, 3499-3507, https://doi.org/10.1021/acs.est.8b05286, 2019.

Xing, Y., Xie, P., Yang, H., Ni, L., Wang, Y., and Tang, W.: Diel variation of methane fluxes in summer in a eutrophic subtropical lake in China, J. Freshwater Ecol., 19, 639-644, 2004. 